\title{
ANALISIS NARASI / DISKURSUS TERHADAP KEBIJAKAN PERHUTANAN SOSIAL DI WILAYAH KERJA PERHUTANI
}

\author{
Narrative Analysis / Discourse of Social Forestry Policies In The Perhutani Working Area \\ Ramli Ramadhan ${ }^{1}$, Risna Noviati Amalia ${ }^{2}$ \\ ${ }^{1}$ Program Studi Kehutanan, Universitas Muhammadiyah Malang, Malang, 65144, Indonesia \\ ${ }^{2}$ Pusat Studi Agraria, IPB, Bogor, 16129, Indonesia \\ E-mail: ramliramadhan@umm.ac.id,risna@apps.ipb.ac.id
}

Diterima: 05 November 2020, Direvisi: 16 November 2020, Disetujui: 21 Desember 2020

DOI: 10.31849/forestra.v16i1.5416

\begin{abstract}
The Social Forestry Policy (PS) in the Perhutani working area has started a new beginning towards the current PS implementation. The issuance of regulation P.39 / 2017 was colored by various narratives / discourses from various actors decorating the journey of the policy issuance above. Using a narrative / discourse analysis approach, this study intends to explore the narratives used by parties in the policy process and those who receive the impact of SF policies. The research method used is descriptive qualitative analysis within-depth interviews with selected respondents proportionally (purposive sampling). The results of the study explain that the narrative of each party is different. The narrative brought by the pro to the policy is based on the condition of the forest and the social conditions of the community around the forest that have not been successfully improved, including the PHBM program that needs to be evaluated. The IPHPS scheme provides opportunities for access and higher profit sharing for the community to manage forests with low cover conditions $(<10 \%)$ and or social conditions that need to be addressed. Perhutani brought a narrative about the current regulation violating the previous regulation, namely PP No.6 / 2007 in conjunction with PP No.3 / 2008 concerning Forest Management and Preparation of Forest Management Plans and PP No.72 / 2010 concerning Perhutani. So that the counter narrative colors the PS policy in the Perhutani working area.
\end{abstract}

Keywords: Narrative / discourse, Social Forestry, Rules of P.39/2017

\begin{abstract}
ABSTRAK
Kebijakan Perhutanan Sosial (PS) di wilayah kerja Perhutani memulai awal baru terhadap pelaksanaan PS saat ini. Terbitnya aturan P.39/2017 diwarnai berbagai narasi / wacana dari berbagai aktor menghiasi perjalanan proses keluarnya kebijakan diatas. Menggunakan pendekatan analisis narasi / diskursus, penelitian ini hendak menggali narasi yang digunakan oleh pihak dalam proses kebijakan dan pihak yang menerima dampak kebijakan PS. Metode
\end{abstract}


penelitian menggunakan analisis deksriptif kualitatif dengan wawancara secara mendalam (indepth interview) terhadap narasumber yang dipilih secara proporsional (purposive sampling). Hasil penelitian menjelaskan bahwa narasi masing-masih pihak berbeda. Narasi yang dibawa oleh pihak pro terhadap kebijakan didasarkan atas kondisi hutan dan kondisi sosial masyarakat di sekitar hutan yang belum berhasil ditingkatkan termasuk program PHBM (Pengelolaan Hutan Bersama Masyarakat) yang perlu di evaluasi. Skema IPHPS memberi peluang akses dan bagi hasil yang lebih tinggi kepada masyarakat untuk mengelola hutan dengan kondisi tutupan yang rendah $(<10 \%)$ dan atau kondisi sosial yang perlu penanganan. Pihak Perhutani membawa narasi tentang aturan saat ini melanggar aturan sebelumnya yakni PP No.6/2007 jo PP No.3/2008 tentang Tata Hutan dan Penyusunan Rencana Pengelolaan Hutan dan PP No.72/2010 tentang Perhutani. Sehingga counter narasi mewarnai keluarnya kebijakan PS di wilayah kerja Perhutani.

Kata kunci: Narasi / diskursus, Perhutanan Sosial, Aturan P.39/2017

\section{PENDAHULUAN}

Perubahan bentuk skema di wilayah Perhutani menimbulkan polemik dan pertarungan narasi / wacana terutama antara Perhutani dan KLHK. Dalam aturan terbaru mensyaratkan bahwa IPHPS dapat diajukan apabila tutupan tegakan hutan kurang dari atau sama dengan $10 \%$ selama 5 tahun atau lebih. Sedangkan pada areal yang terdapat konflik dengan masyarakat dapat diberikan IPHPS sehingga otomatis skema PHBM dapat tergantikan dengan skema baru tersebut.

Pergeseran bentuk PS dari PHBM ke IPHPS mengindikasikan bahwa PHBM selama ini dianggap belum berhasil meningkatkan partisipasi dan pendapatan masyarakat sekitar hutan yang tergabung dalam Lembaga Masyarakat Desa Hutan
(LMDH) (Pratama, 2019). Selanjutnya dengan adanya IPHPS juga mengindikasikan justru banyak tegakan hutan yang rusak dengan melihat indikator tutupan lahan. Sejak dikeluarkannya aturan P.39/2017, banyak pertentangan berupa narasi baik secara pe Sejak tahun 2014 Pemerintah dibawah Kementrian Lingkungan Hidup dan Kehutanan (KLHK) memasang target dan komitmen memperluas kebijakan Perhutanan Sosial (PS). Total target potensi hutan yang masuk dalam skema PS adalah 12,7 juta ha. KLHK merespon dengan membuat Peta Indikatif Areal Perhutanan Sosial (PIAPS) yang bertujuan memetakan lahan potensial yang masuk ijin PS. (Fisher et al., 2018). Saat ini, ada 5 skema PS beroperasi di Indonesia 
seperti tertuang dalam aturan Permen LHK.83/2016 tentang Perhutanan Sosial yakni: hutan desa, hutan kemasyarakatan, hutan tanaman rakyat, kemitraan kehutanan dan hutan adat (KLHK, 2016). Tujuan sebenarnya dari PS adalah menyediakan kesempatan kepada masyarakat lokal, khususnya untuk meningkatkan nilai sosial, ekonomi dan lingkungan melalui praktek agroforestry (Rakatama \& Pandit, 2020).

Perkembangan PS kian meluas tidak hanya di hutan milik negara namun menyasar di hutan yang berada di wilayah Perum Perhutani. Hal ini ditandai dengan keluarnya Permen LHK P.39/2017. Aturan ini memulai babak baru program PS di jawa yang sebelumnya dikenal dengan nama Pengelolaan Hutan Bersama Masyarakat (PHBM) menjadi bentuk IPHPS (Ijin

\section{METODE PENELITIAN}

Penelitian ini menggunakan analisis diskursus/narasi yang dapat memahami suatu proses pembuatan dan pelaksanaan kebijakan melalui makna yang diberikan terhadap suatu fenomena (Kartodihardjo, 2017). Mencari narasi yang mendasari pemikiran terhadap munculnya suatu
Pemanfaatan Hutan Perhutanan Sosial) maupun Kemitraan Kehutanan (Kulin-KK) (Erbaugh, 2019)ndekatan aturan perundangundangan maupun pendekatan fakta kondisi hutan maupun sosial masyarakat dilapangan. Berbekal identifikasi permasalahan diatas, penelitian ini hendak mengidentifikasi proses keluarnya kebijakan P.39/2017 ditinjau dari dinamika narasi maupun wacana yang dibawa oleh pihak-pihak yang berkepentingan terhadap keluarnya aturan ini. Melalui analisis diskursus/narasi dapat menggali bagaimana suatu agenda dibuat dan apa masalah yang mendasari oleh aktor pembuat sehingga kebijakan tersebut dikeluarkan, serta bagaimana dengan aktor yang menerima dampak kebijakan menanggapi narasi yang keluar dari pembuat kebijakan.

kebijakan menjadi hal yang sangat penting, untuk dapat menjawab bagaimana agenda dibuat dan masalah ditetapkan dalam kebijakan tersebut. Hal tersebut dapat diketahui bagaimana para pembuat dan pelaku kebijakan mengungkapkannya kepada publik melalui bahasa-bahasa yang 
digunakannya (Kartodihardjo, 2017).

Melalui pendekatan narasi berupa teks maupun narasi komunikasi (Arts dan Buizer, 2009) dapat memahami kerangka berfikir yang digunakan dalam pembuatan suatu kebijakan.

Identifikasi lingkup analisis kebijakan membedakan lima tema diantaranya (Runhaar et al dalam (Kartodihardjo, 2017):

\section{Analisis Isi Kebijakan. Beberapa} contoh pertanyaan meliputi apa tujuan kebijakan?, apa definisi masalah yang mendasari tujuan kebijakan? Apakah asumsi dibalik kebijakan tersebut valid?

2. Proses Terjadinya Kebijakan.

Beberapa contoh pertanyaan meliputi Apa pengaruh berbagai aktor terhadap proses terjadinya kebijakan? Bagaimana ilmu pengetahuan mengambil peran atau disingkirkan? Kepentingan apa dan siapa saja yang mengambil peran dalam penetapan kebijakan itu?

3. Organisasi Kebijakan. Beberapa contoh pertanyaan meliputi: domain kebijakan apa saja yang terlibat dalam isu pembangunan berkelanjutan?
Bagaimana Pemerintah dapat efektif mengarahkan kebijakan ke level pemerintahan di bawahnya?

4. Dampak Kebijakan. Beberapa contoh pertanyaan meliputi: Apakah suatu kebijakan dapat mencapai tujuannya? Apakah ada efek samping yang merugikan atau menguntungkan? Apakah stakeholder mengevaluasi dampak kebijakan dengan cara yang sama dengan pemerintah atau tidak? Faktor apa yang dapat menjelaskan keberhasilan atau kegagalan kebijakan yang diteliti?

5. Konteks Kebijakan. Beberapa contoh pertanyaan meliputi: Bagaimana lahirnya dan isi kebijakan dipengaruhi oleh perkembangan politik, ekonomi, dan sosial-budaya atau kebijakan internasional?

Analisis narasi/diskursus memenuhi sebagai metode penelitian untuk menjawab tema kebijakan yakni analisis isi kebijakan, proses terjadinya kebijakan, dampak kebijakan dan konteks kebijakan. Sedangkan tema organisasi kebijakan perlu dijawab menggunakan metode analisis stakeholder. 
Waktu Penelitian dilaksanakan pada kurun waktu bulan Desember 2019 hingga Maret 2020. Lokasi Penelitian dilaksanakan di beberapa lokasi yaitu Kementrian Kehutanan dan Lingkungan Hidup (KLHK), Perum Perhutani Jakarta, dan Bogor. Responden dipilih dengan metode purposive sampling (terhadap aktor-aktor yang terlibat dan mengetahui proses keluarnya kebijakan). Teknik pengumpulan data dilaksanakan melalui wawancara mendalam kepada narasumber yang paham terhadap proses pembuatan kebijakan, studi dokumen perundang-undangan, studi dokumen dan penggalian data dari forum diskusi yang membahas kebijakan tersebut. Data yang dikumpulkan berupa narasi yang dikeluarkan oleh narasumber terhadap proses kebijakan P.39/2017 melalui wawancara maupun forum diskusi secara umum dan narasi teks yang dihasilkan melalui studi literature, studi peraturan perundang-undangan.

Tabel 1. Daftar Narasumber Penelitian

\begin{tabular}{llll}
\hline No & Pemerintah / KLHK & Perhutani & Akademisi \\
\hline $\mathbf{1}$ & Kelompok Kerja PS & Dewan Pengawas & Akademis (2 Narasumber) \\
& $\begin{array}{l}\text { Nasional (Pokja PS) (1 } \\
\text { Narasumber) }\end{array}$ & Perhutani (1 Narasumber) & \\
\hline $\mathbf{2}$ & $\begin{array}{l}\text { Sekretaris Reforma Agraria/ } \\
\text { Pokja PS Nasional } \\
\text { (1Narasumber) }\end{array}$ & Perum Perhutani (2 \\
& Narasumber) & \\
$\mathbf{3}$ & $\begin{array}{l}\text { Direktorat Jenderal } \\
\text { Planologi KLHK (1 } \\
\text { Narasumber) }\end{array}$ & & \\
\hline $\mathbf{4}$ & $\begin{array}{l}\text { Kantor Staf Presiden (KSP) } \\
\text { (1 Narasumber) }\end{array}$ & \\
\hline
\end{tabular}

\section{HASIL DAN PEMBAHASAN}

Narasi Kemunculan PS di Wilayah Kebijakan PS terutama di wilayah kerja

\section{Perhutani}

Analisis isi kebijakan terkait tujuan dan definisi masalah yang mendasari lahirnya kebijakan dijawab pada bagian ini.
Perhutani merupakan satu kebijakan yang bersifat khusus karena merupakan lex spesialis (hukum khsuus) di Pulau Jawa. Sebelumnya melalui P.83/2016 tentang 
Perhutanan Sosial di Indonesia, penerapan PS di wilayah Perhutani terbatas pada skema Kemitraan Kehutanan yang kemudian dikenal dengan Kulin-KK. Skema lain seperti $\mathrm{HKm}$ dan Hak Pengelolaan Hutan Desa (HPHD) dapat diterapkan di wilayah perhutani namun terbatas hanya di hutan lindung. Hal tersebut memunculkan diskursus / narasi berupa desakan dari para Civil Society Organization (CSO). Berdasarkan wawancara dengan salah satu anggota Pokja PS Nasional, menyebutkan bahwa P.83/2016 tidak menjawab permasalahan hutan yang ada di Jawa. Penetapan HPHD dan $\mathrm{HKm}$ di wilayah Perhutani tidak menyasar pada inti permasalahan hutan di Jawa yang sebenarnya kerusakan hutan, konflik lahan dan sosial banyak terjadi di hutan produksi.

Terdapat beberapa narasi yang dihimpun dari narasumber atau aktor tingkat nasional terhadap definisi masalah yang mendasari lahirnya kebijakan PS selain adanya desakan dari CSO. Narasi dihimpun dari narasumber antara lain: Pokja PS Nasional, Sekretaris Reforma Agraria KLHK sekaligus anggota Pokja Nasional, Staff KSP bidang Agraria, Mantan Dirjen
Planologi KLHK dan narasi teks dari CSO Koalisi Pemulihan Hutan (KPH) Jawa seperti terhimpun dibawah ini: pertama, kuasa lahan oleh Perhutani di jawa yang mencapai 2,4 juta Ha tidak dimanfaatkan secara optimal terutama untuk memproduksi tanaman pangan bagi masyarakat sekitar (distribusi hutan bagi pangan). Kedua, Kondisi tegakan dan tutupan hutan Perhutani yang rendah. Ketiga, Program PHBM yang dilaksanakan selama 15 tahun belum berhasil meningkatkan status sosial ekonomi masyarakat dan memperbaiki kondisi hutan. Keempat, Konflik lahan antara Perhutani dan masyarakat masih terjadi.

Narasi diatas merupakan diskursus penting terhadap kemunculan PS di wilayah Perhutani. Pihak pemerintah melemparkan narasi diantaranya kondisi hutan melalui tutupan yang rendah serta kondisi sosial ekonomi masyarakat yang tidak meningkat meskipun terdapat program PHBM yang berjalan selama 15 tahun. Program PHBM menjadi sorotan karena beberapa hal menurut wacana yang berkembang. Pertama, PHBM belum mampu menggandeng masyarakat dalam memperbaiki kondisi tutupan hutan di 
beberapa areal kerja Perhutani. Kedua, masih lemahnya pemahaman petani hutan anggota LMDH terhadap PHBM dan ketiga, adanya indikasi penyimpangan pelaksanaan PHBM yang hanya menguntungkan pihak-pihak tertentu saja. Beberapa penelitian menunjukkan bahwa program PHBM perlu dievaluasi keberadaannya sehingga masyarakat terlibat secara aktif sebagai subyek pengelola hutan (Maryudi, 2011)(Peluso, 1993)(Sumanto, 2009).

Proses kebijakan PS memang tergolong cepat dalam perumusannya sehingga banyak pihak terutama Perhutani mempertanyakan dampak kebijakan di lapangan. Menurut hasil wawancara dengan salah satu narasumber yang memahami proses kebijakan, menjelaskan bahwa aturan P.39/2017 merupakan rangkain proses panjang yang tidak hanya datang dari pemerintah atau KLHK melainkan karena dorongan dari aktor eksternal yakni peran CSO. KLHK dan CSO bersama-sama membawa narasi kepentingan terkait dengan kondisi hutan di jawa yang terus menurun serta taraf hidup masyarakat sekitar hutan tidak membaik meskipun telah ada PHBM. CSO yang tergabung dalam
Koalisi Pemulihan Hutan (KPH) memiliki kepentingan untuk memberikan hak pengelolaan hutan kepada desa. Sehingga hak yang sebelumnya dikuasai oleh Perhutani dapat kembali dikelola oleh desa.

Selain peran aktor diatas, kebijakan PS keluar karena adanya konteks kebijakan yang melatarbelakangi. Salah satunya kebijakan Presiden Joko Widodo yang mencanangkan program Perhutanan Sosial di seluruh Indonesia sebesar 12,7 juta Ha. Program ini kemudian menyasar pelaksanaan PS di jawa yang selama ini dikuasai oleh Perhutani. Selain itu, dalam konteks peran institusi desa dalam mengelola hutan selama ini belum terlihat meskipun sudah muncul UU tentang Desa No.6/2014. Desa diharapkan menjadi insitusi yang memiliki hak pengelolaan hutan desa yang selama ini ada dalam kewenangan Perhutani.

\section{Counter Narasi Kebijakan}

Narasi berbeda dilayangkan oleh pihak kontra terhadap keluarnya kebijakan yakni pihak Perhutani. Perhutani merasa dalam proses pembentukan kebijakan tidak dilibatkan oleh Pemerintah. Bahkan Perkumpulan Pensiunan Pegawai Perhutani 
(4P) melayangkan gugatan ke Mahkamah Agung (MA) karena menolak aturan P.39/2017 tersebut. Beberapa narasi yang keluar dari pihak Perhutani antara lain pertama, bahwa aturan P.39/2017 telah menabrak aturan yang ada diatasnya terutama PP No.6/2007 jo PP No.3/2008 tentang Tata Hutan dan Penyusunan Rencana Pengelolaan Hutan terutama di pasal 48 yang menyatakan bahwa pemberi izin dilarang mengeluarkan izin dalam wilayah kerja BUMN bidang kehutanan yang telah mendapat pelimpahan untuk menyelenggarakan pengelolaan hutan. Kedua, ialah narasi yang menjelaskan bahwa P.39/2017 telah menabrak aturan yang ada di PP No.72/2010 tentang Perhutani. Pihak perhutani berpandangan bahwa mereka diberi pelimpahan atau pendelegasian pengelolaan hutan jawa. Ketiga, kebijakan baru tersebut dapat menimbulkan konflik horizontal berkaitan dengan keberadaan LMDH yang sudah ada. Keempat, bahwa potensi menimbulkan kerusakan hutan dan bencana lingkungan akibat kesalahan kelola tanpa perencanaan berbasis kelestarian menjadi besar. Hal ini karena hak dan akses masyarakat yang mempunyai ijin lebih besar dibanding ketika masih dalam program PHBM.

Dari sini terjadi pertarungan narasi antar dua institusi yaitu KLHK dan Perhutani. KLHK memiliki prespektif dalam menjawab narasi yang dilemparkan oleh Perhutani. Dalam hal menabrak aturan PP No.6/2007 terutama di pasal 48 yang menyatakan bahwa pemberi izin dilarang mengeluarkan izin dalam wilayah kerja BUMN bidang kehutanan yang telah mendapat pelimpahan untuk menyelenggarakan pengelolaan hutan. KLHK mempunyai perspektif bahwa ketentuan tersebut dibuat untuk mengantisipasi pembentukan BUMN pengelola hutan di luar jawa. Selain itu obyek yang diatur pada PP 6/2007 adalah hutan alam dan produksi diluar jawa bukan di jawa. Hal lain yang menjadi narasi bahwa P.39/2017 menabrak aturan yang ada di PP No.72 Tahun 2010 tentang Perhutani. Perhutani berpandangan bahwa mereka diberi pelimpahan atau pendelegasian pengelolaan hutan jawa. Namun KLHK melalui aturan tersebut di pasal 3 ayat 4 menyatakan bahwa pengelolaan hutan di hutan negara oleh perusahaan tidak termasuk kegiatan yang merupakan 
kewenangan publik misalnya pemberian izin pemanfaatan hutan, yang merupakan kewenangan KLHK. Terhadap adanya narasi bawah potensi konflik horizontal antara LMDH dengan penerima IPHPS, Pemerintah mengatakan bahwa peran LMDH dan PHBM tetap ada dengan menata ulang penggarapnya by name by address dengan pola kemitraan / Kulin-KK sesuai P.83/2016. Dengan skema Kulin-KK hak dan kewajiban penggarap sama dengan hak dan kewajiban pemegang IPHPS dan menyingkirkan pemodal yang tidak berhak sebagai penggarap.

\section{IPHPS dan Kulin-KK}

Kebijakan P.39/2017 memunculkan skema baru dalam perjalanan PS di Perhutani sejak dimulai tahun 1984-1986. Skema atau model tersebut bernama IPHPS. Seperti yang sudah dijelaskan diatas bahwa IPHPS merupakan jawaban atas areal Perhutani yang tidak bisa dikelola secara efektif dengan tutupan lahan $<10 \%$ selama 5 tahun berturut-turut berdasar Pemetaan Indikatif Areal Perhutanan Sosial (PIAPS). Areal ini juga dapat diterapkan pada tutupan $>10 \%$ dalam hal terdapat kondisi sosial yang memerlukan penanganan secara khusus. Semisal masih terdapat konflik lahan antara masyarakat dan Perhutani di areal tersebut. Contoh kasus ialah Muara Gembong dimana Perhutani tidak dapat mengelola secara efektif melalui PHBM karena justru banyak dikuasai oleh orang diluar. Skema IPHPS menurut hasil wawancara, dibuat dengan tujuan untuk mengurangi ketimpangan akses atas lahan antara rakyat dan korporasi yang selama ini sangat timpang. Konsep dasar dari skema ini dibuat sama dengan konsep pada ijin konsesi di hutan luar jawa seperti Hutan Tanaman Industri (HTI) atau sekarang yang lebih dikenal dengan Ijin Usaha Pemanfaatan Hasil Hutan Kayu (IUPHHK).

$$
\text { Dalam pelaksanaan dan }
$$
implementasinya tidak hanya menggunakan skema IPHPS namun pemohon maupun pengusul dapat mengajukan ijin dengan skema kemitraan. Skema kemitraan ini diterapkan di areal Perhutani mengacu pada P.83/2016 pasal 40 bahwa pengelola hutan atau pemegang ijin wajib melaksanakan pemberdayaan masyarakat setempat melalui kemitraan kehutanan. Pengelola hutan disini termasuk Perhutani sebagai badan usaha milik negara, sehingga dari sini 
muncul istilah Kulin-KK (Pengakuan dan Perlindungan Kemitraan Kehutanan). Istilah Kulin-KK hanya muncul di jawa merupakan kelanjutan dari PHBM yang sebelumnya sudah berjalan dengan perbaikan mengikuti aturan di P.83/2016. Ada perbedaan mendasar antara IPHPS dan Kulin-KK, apabila IPHPS berdasarkan ijin pemanfaatan namun di Kulin-KK melalui proses kesepakatan yang dituangkan dalam Naskah Kesepakatan Bersama (NKK) yang diatur dalam Perdirjen PSKL No. 18 Tahun 2016.

Berdasar hasil pengamatan menunjukkan bahwa skema Kulin-KK dianggap sama dengan program PHBM selama ini meskipun dengan beberapa perbaikan. Banyak LMDH yang telah mengikuti program PHBM dan menjalin kerjasama yang baik dengan Perhutani melanjutkan dengan mengajukan skema Kulin-KK. Sedangkan dari pihak CSO lebih mendorong masyarakat mengajukan skema IPHPS karena bagi hasil (sharing) yang didapatkan lebih besar, selain ada persyaratan khusus terkait kondisi lahan dan sosial wilayah tersebut. Menurut pasal 8 ayat 2 dijelaskan bahwa keuntungan bersih pemegang ijin IPHPS untuk tanaman pokok hutan pemegang IPHPS mendapatkan $70 \%$ sedangkan Perhutani $30 \%$. Hal ini tentu berbeda pada saat PHBM dimana LMDH memperoleh lebih rendah dibanding Perhutani. Hingga tahun 2018 sejak aturan dikeluarkan, menunjukkan banyak masyarakat yang mengajukan skema IPHPS meskipun secara total Kulin-KK tetap yang masih banyak diajukan. Gambar 1. dibawah merupakan data yang menunjukkan capaian pengajuan ijin antara skema IPHPS dan Kulin-KK. Data dibawah menunjukkan kelompok masyrakat yang mengajukan ijin di tiga Divre (Divisi Regional) Perhutani. Wilayah yang tutupan hutan $<10 \%$ dan memerlukan penangangan khusus seperti konflik sosial dengan Perhutani maka mengajukan skema IPHPS. 

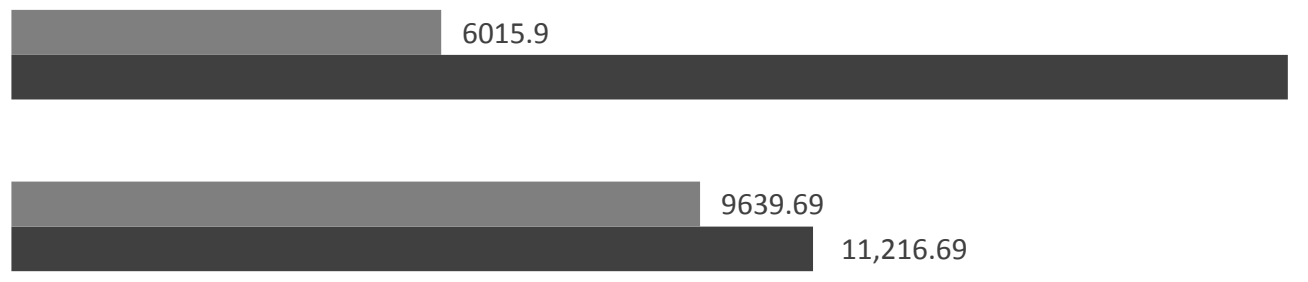

\begin{tabular}{l}
\hline \multicolumn{1}{|c|}{$1,102.07$} \\
\cline { 2 - 4 }
\end{tabular}

Sumber: Diolah dari data primer

Gambar 1. Capaian Perhutanan Sosial berdasar Luas Lahan (Ha) Hingga Tahun 2018

Gambar diatas menunjukkan bahwa skema Kulin-KK hingga tahun 2018 merupakan skema yang paling banyak diajukan oleh masyarakat bekerjasama dengan Perhutani kecuali di Divre Jateng dimana banyak masyarakat mengajukan IPHPS sebesar 8.693 ha. Sedangkan di Divre Jatim juga menunjukkan capaian

\section{KESIMPULAN DAN SARAN}

\section{A. Kesimpulan}

Narasi dibalik keluarnya peraturan mengenai Perhutanan Sosial di wilayah kerja Perhutani muncul dari pihak Pemerintah melalui KLHK dan CSO dengan pihak Perhutani yang menerima dampak terhadap kebijakan tersebut.
IPHPS yang tinggi meskipun di Jabar cenderung lebih rendah. Narasi mengenai Kulin-KK yang merupakan penjabaran dari skema PHBM dan IPHPS sebagai skema baru yang diusung berdasar tujuan utama kebijakan ini tentu akan terus bergulir mengingat target penerapan PS diseluruh Indonesia sampai pada tahun 2022.

Narasi yang berkembang dari aktor pemerintah maupun CSO menyebutkan bahwa Perhutani sebagai pemegang mandat hutan di jawa belum mampu untuk memperbaiki kondisi hutan dan kondisi sosial masyarakat. Pemanfaatan lahan hutan sebagai lumbung pangan 
belum berjalan maksimal karena akses masyarakat didalam mengelola hutan terbatas. Perhutani membawa narasi bahwa kebijakan baru tersebut menabrak beberapa aturan sebelumnya seperti PP No.6/2007 jo PP No.3/2008 dan PP No.72/2010 tentang Perhutani. Sehingga terjadi counter narasi dalam perjalanan kebijakan PS di wilayah kerja Perhutani dengan aktor dan kepentingan yang berbeda.

\section{B. Saran}

Perlunya penelitian lebih lanjut pada tahap implementasi kebijakan dengan melihat pelaksanaan di lapangan. Selanjutnya bagaimana kebijakan tersebut diperkuat untuk mengatasi kelemahan-kelemahan yang terjadi selama proses implementasi.

\section{UCAPAN TERIMA KASIH}

Ucapan terima kasih sebesar-besarnya sehingga penelitian ini terlaksana. Hal tersebut terwujud karena adanya dukungan materiil dan dukungan akses oleh Sajogyo Institute yang ketika itu mempunyai agenda terhadap kebijakan PS di tingkat nasional dan terutama di Jawa Barat.

DAFTAR PUSTAKA
Erbaugh, J. T. (2019). Responsibilization and social forestry in Indonesia. Forest Policy and Economics, 109(June), 102019.

https://doi.org/10.1016/j.forpol.2019.1 02019

Fisher, M. R., Moeliono, M., Mulyana, A., Yuliani, E. L., Adriadi, A., Kamaluddin, Judda, J., \& Sahide, M. A. K. (2018). Assessing the New Social Forestry Project in Indonesia: Recognition, Livelihood and Conservation? International Forestry Review, 20(3), 346-361. https://doi.org/10.1505/146554818824 063014

Kartodihardjo. (2017). Analisis Kebijakan Pengelolaan Sumber Daya Alam: Diskursus-Politik-Aktor-Jaringan (pertama). Sajogyo Institute.

Maryudi, A. (2011). The contesting aspirations in the forests: Actors, Interests, and Power in Community Forestry in Java, Indonesia (Issue January 2011). https://www.researchgate.net/profile/A hmad_Maryudi/publication/30340279 6_The_Contesting_Aspirations_in_the _Forests_Actors_Interests_and_Power _in_Community_Forestry_in_Java_In donesia/links/5a79086ca6fdcc4ffe90be 77/The-Contesting-Aspirations-in-theForests-

Peluso, N. L. (1993). "Traditions" of forest control in Java: implications for social forestry and sustainability." Global Ecology \& Biogeography Letters, 3(46), $183-157$. https://doi.org/10.2307/2997766 
Pratama, A. A. (2019). Lessons Learned from Social Forestry Policy in Java Forest: Shaping the Way Forward for New Forest Status in ex-Perhutani Forest Area. Jurnal Ilmu Kehutanan, 13(2), 127. https://doi.org/10.22146/jik.52092

Rakatama, A., \& Pandit, R. (2020). Reviewing social forestry schemes in Indonesia: Opportunities and challenges. Forest Policy and Economics, 111(1), 102052. https://doi.org/10.1016/j.forpol.2019.1 02052

Sumanto, S. E. (2009). Kebijakan pengembangan perhutanan sosial dalam perspektif resolusi konflik. Jurnal Analisis Kebijakan Kehutanan, 6(1), 13-25. 